\title{
10 CFR 830 Major Modification \\ Determination for Replacement of ATR Primary Coolant Pumps and Motors
}

May 2011

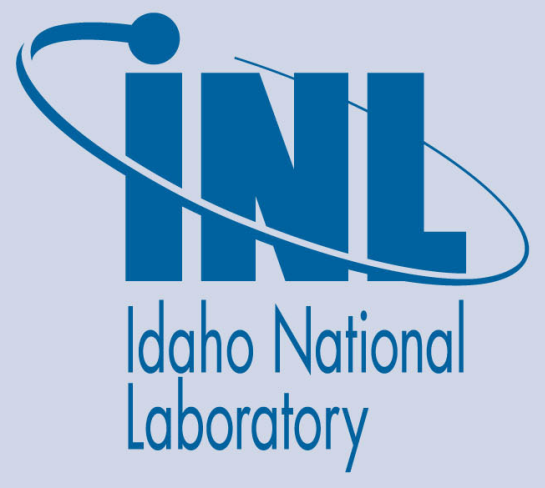

The INL is a U.S. Department of Energy National Laboratory operated by Battelle Energy Alliance 
INL/EXT-11-22063

\title{
10 CFR 830 Major Modification Determination for Replacement of ATR Primary Coolant Pumps and Motors
}

May 2011

\author{
Idaho National Laboratory \\ Idaho Falls, Idaho 83415
}

http://www.inl.gov

Prepared for the

U.S. Department of Energy

Office of Nuclear Energy

Under DOE Idaho Operations Office

Contract DE-AC07-05ID14517 
INL/EXT-11-22063

Revision 0

\section{DISCLAIMER}

This information was prepared as an account of work sponsored by an agency of the U.S. Government. Neither the U.S. Government nor any agency thereof, nor any of their employees, makes any warranty, expressed or implied, or assumes any legal liability or responsibility for the accuracy, completeness, or usefulness, of any information, apparatus, product, or process disclosed, or represents that its use would not infringe privately owned rights. References herein to any specific commercial product, process, or service by trade name, trade mark, manufacturer, or otherwise, does not necessarily constitute or imply its endorsement, recommendation, or favoring by the U.S. Government or any agency thereof. The views and opinions of authors expressed herein do not necessarily state or reflect those of the U.S. Government or any agency thereof. 
INL/EXT-11-22063

Revision 0

\section{Advanced Test Reactor}

\section{CFR 830 Major Modification Determination \\ for}

\section{Replacement of ATR Primary Coolant Pumps and Motors}

INL/EXT-11-22063

Revision 0

May 2011

Developed by:

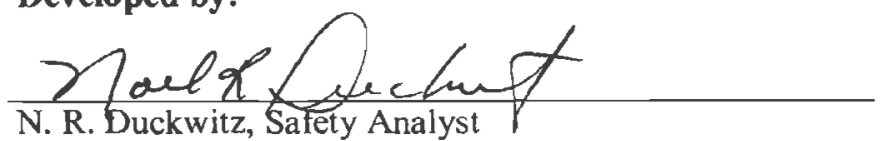

N. R. Duckwitz, Safety Analyst

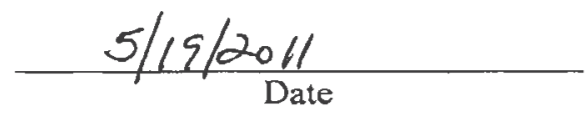

Approved by:

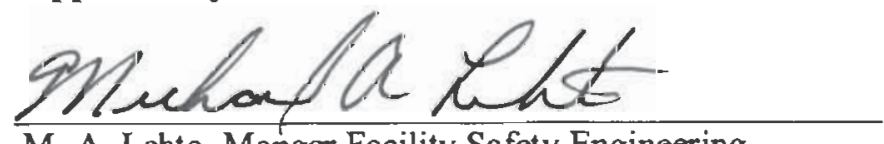

M. A. Lehto, Manger Facility Safety Engineering
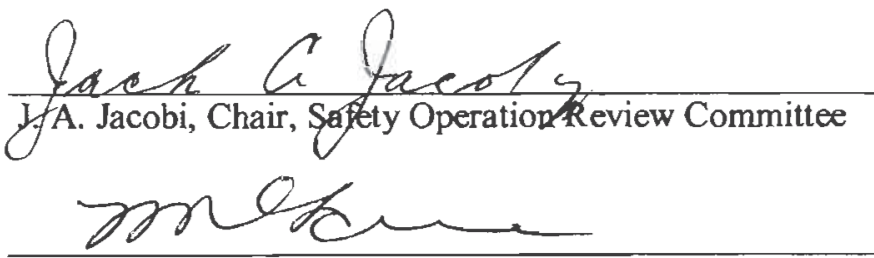

M. D Loye, Director ATR Complex Program- Oper An on's

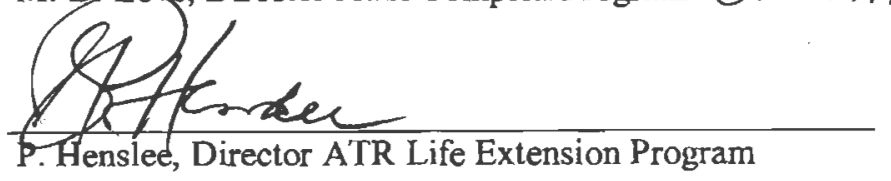

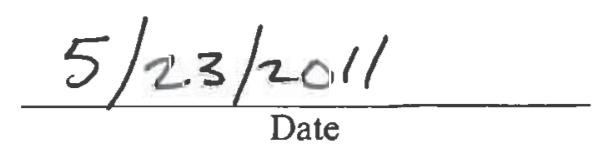

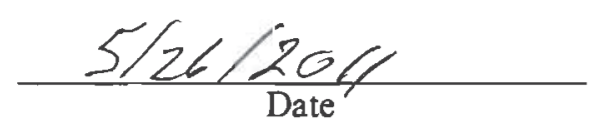




\section{CONTENTS}

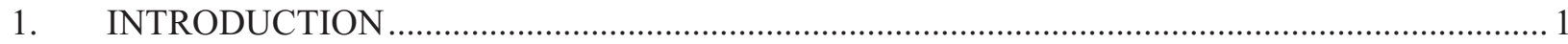

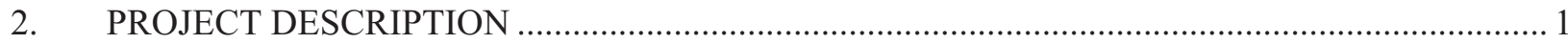

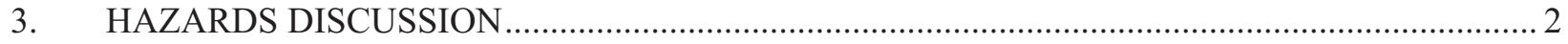

4. MAJOR MODIFICATION EVALUATION CRITERIA …..................................................... 3

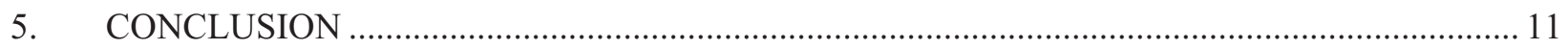

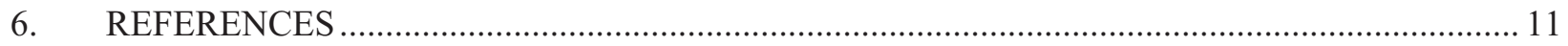

TABLES

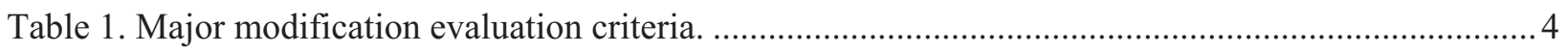

FIGURES

Figure 1. Facility modification process (taken from DOE-STD-1189, Figure 8-1)................................ 10 


\section{DEFINITIONS}

Major modification - A modification to a DOE nuclear facility that is completed on or after May 9, 2001 that substantially changes the existing safety basis for the facility. (10 CFR 830)

Nuclear facility - A reactor or a nonreactor nuclear facility where an activity is conducted for or on behalf of DOE and includes any related area, structure, facility, or activity to the extent necessary to ensure proper implementation of the requirements established by 10 CFR 830. (10 CFR 830)

Safety basis - The documented safety analysis and hazard controls that provide reasonable assurance that a DOE nuclear facility can be operated safely in a manner that adequately protects workers, the public, and the environment. (10 CFR 830)

Simple modification - A modification to a DOE nuclear facility not requiring a new or revised hazard analysis and accident analysis and new safety controls. (DOE-STD-1189)

Substantial change to the existing safety basis - Required by facility modification that is considered a major modification. (DOE-STD-1189) 


\section{ACRONYMS and ABBREVIATIONS}

$\begin{array}{ll}\text { ATR } & \text { Advanced Test Reactor } \\ \text { CDF } & \text { core damage frequency } \\ \text { CFR } & \text { Code of Federal Regulation } \\ \text { CSDR } & \text { conceptual safety design report } \\ \text { DOE } & \text { U.S. Department of Energy } \\ \text { ECP } & \text { emergency coolant pump } \\ \text { ESF } & \text { engineering safety features } \\ \text { GFE } & \text { government furnished equipment } \\ \text { HC } & \text { hazard category } \\ \text { INL } & \text { Idaho National Laboratory } \\ \text { LOCA } & \text { loss-of-coolant-accident } \\ \text { MAR } & \text { material-at-risk } \\ \text { MCA } & \text { material condition assessment } \\ \text { NE } & \text { Office of Nuclear Energy } \\ \text { NPH } & \text { natural phenomena hazards } \\ \text { PCP } & \text { primary coolant pump } \\ \text { PDSA } & \text { preliminary documented safety analysis } \\ \text { PSDR } & \text { preliminary safety design report } \\ \text { SAR } & \text { safety analysis report } \\ \text { SC } & \text { safety class } \\ \text { SDS } & \text { safety design strategy } \\ \text { SS } & \text { safety significant } \\ \text { SSC } & \text { structure, system or component } \\ \text { STD } & \text { standard } \\ \text { TSR } & \text { technical safety requirements } \\ \text { UFSAR } & \text { updated final safety analysis report } \\ \text { UPS } & \text { VFD }\end{array}$


INL/EXT-11-22063

Revision 0

\title{
10 CFR 830 Major Modification Determination
}

\author{
for \\ Replacement of ATR Primary Coolant Pumps and \\ Motors
}

\section{INTRODUCTION}

The Advanced Test Reactor (ATR), located in the Advanced Test Reactor Complex of the Idaho National Laboratory (INL), was constructed in the 1960s for the purpose of irradiating reactor fuels and materials. Other irradiation services, such as radioisotope production, are also performed at ATR.

The continued safe and reliable operation of the ATR is critical to the Department of Energy (DOE) Office of Nuclear Energy (NE) mission. While ATR is safely fulfilling current mission requirements, a variety of aging and obsolescence issues challenge ATR engineering and maintenance personnel's capability to sustain ATR over the long term. First documented in a series of independent assessments, beginning with an OA Environmental Safety and Health Assessment conducted in 2003, the issues were validated in a detailed Material Condition Assessment (MCA) conducted as a part of the ATR Life Extension Program in 2007.Accordingly, near term replacement of aging and obsolescent original ATR equipment has become important to ensure ATR capability in support of NE's long term national missions. To that end, a mission needs statement has been prepared for a non-major system acquisition which is comprised of three interdependent subprojects. The first project will replace the existent dieselelectrical bus (E-3), switchgear, and the 50-year-old obsolescent marine diesels with commercial power that is backed with safety-related emergency diesel generators, switchgear, and uninterruptible power supply (UPS). The second project, the subject of this major modification determination, will replace the four, obsolete, original primary coolant pumps (PCPs) and motors.

Completion of this and the two other age-related projects (replacement of the ATR diesel bus [E-3] and switchgear and replacement of the existent emergency firewater injection system) will resolve major age-related operational issues plus make a significant contribution in sustaining the ATR safety and reliability profile.

\section{PROJECT DESCRIPTION}

This project description is based on the drafted Mission Need Statement for Advanced Test Reactor Reliability Sustainment Project, ${ }^{1}$ alternative concepts study for the ATR PCP replacement, ${ }^{2}$ and the final scoping study report for the ATR PCP replacement. ${ }^{3}$ (Note that further system studies may identify the need for changes.)

The ATR MCA validated ATR staff concern related to the long-term sustainability and reliability of the plant's four HSB Bingham horizontal centrifugal primary coolant pumps. Four pumps and associated drive motors are currently installed. Normal reactor operation requires two or three pumps to be operating with one pump idle (an installed spare). The pumps and their peripherals, including their motors and the butterfly valve (flow control valve to control reactor pressure differential) installed in the PCP discharge piping, are all original plant equipment. The pump manufacturer is no longer in business and, consequently, the pumps lack adequate vendor spares and technical support. Plant personnel must work with third party vendors to obtain support beyond in-house capabilities. The equipment obsolescence issues are exacerbated by the antiquated pumps' high maintenance mechanical seals (primary coolant leak source) and high maintenance pump/motor shaft coupling. Both components, like the pumps, are of 
antiquated design making them increasingly difficult to maintain due to a similar lack of vendor support and the need to execute maintenance work dressed out in anti-contamination protective clothing. The balance/flow control valve, flanged and bolted into the pump discharge piping, presents its own set of vulnerabilities, including minor primary coolant flange leaks and related contamination issues. Finally, the antiquated pump configuration imposes a number of high cost maintenance protocols and visual checks, to verify pump readiness/leak-rate acceptability before every plant start-up. The pre-start-up checks also require time consuming and costly radiation-related space entry and exit protocols. All these issues will be readily mitigated by replacing the plant's nearly 50 -year-old pumps and peripherals with equivalent, current technology, pumps and supporting peripherals.

Like-for-like replacement pumps must, as a minimum, match all operating parameters specified for the currently installed, but now obsolete pumps. To eliminate the need for currently required pre-startup leak checks, the consequent pump cubical contamination issues, and to minimize the current burden on ATR operations and maintenance staff, the replacement pumps should be of leak proof design under normal operating conditions (a readily available design attribute incorporated into current technology pumps designed for nuclear service ). Replacement pumps should have the capability of being started and/or shutdown to enable flow load transfer without having to shutdown the reactor, again, a feature now incorporated into selected pump designs suitable for nuclear service. Review of available pump designs support the option of variable speed capability via a feature known in industry as variable frequency drive (VFD). Incorporating this technology will facilitate replacement of or, more precisely, eliminate the current ATR requirement for separate emergency coolant pumps (ECPs). As a readily available design feature of available replacement pumps, its recommended adoption will not only enhance system reliability, it with further reduce operations and maintenance staff burden at ATR.

Preliminary functional and operational requirements and criteria for the PCP replacement include the following:

- Provide flow rates and pressure equivalent to the currently installed primary coolant pumps

- Operate with the lowest achievable leak rate

- Provide sufficient emergency flows to support elimination of the installed emergency coolant pumps

- Provide variable frequency drive to support removal of the existent flow control valve

- Design for a minimum 40 year design life.

\section{HAZARDS DISCUSSION}

\section{Material at Risk}

The ATR material at risk (MAR) consists of the reactor core, the radioactive materials (irradiated fuel elements and other hardware) stored in the canal, isotope production targets, and experiments containing fuel and non-fueled components. The ATR is a Category A reactor with an operating power level up to $250 \mathrm{MW}_{\mathrm{t}}$ and, as such, has a radioactive material inventory with the potential for significant off-site consequences. The proposed project has no effect on the quantity of MAR.

Fires and/or Explosions

The replacement PCPs and motors do not introduce any new fire/explosion hazards.

\section{Natural Phenomena Hazards}

Natural phenomena hazards (NPHs), including earthquakes (seismic events), extreme wind, tornado, flood, volcanic, and lightning, are potential hazards to the facility for causing building damage and/or failure of safety-related operational equipment. These NPH hazards were evaluated in the ATR Upgraded Final Safety Analysis (UFSAR) ${ }^{4}$ for existing facilities in support of current operations. Based on the UFSAR analysis, the current PCPs (Equipment Nos. 670-M-6, -7, -8 and -9) are classified as safety 
related (Category - Non-Plant Protection System). The PCPs are qualified as a passive Seismic Category I components (i.e., only the integrity of the passive pressure boundary is credited to function under accident/NPH conditions; the pump/motor it is not required to perform its active function in an accident/NPH environment). The PCP replacement concept, as discussed in Section 2 above, includes utilizing the current advanced VFD technology with new PCPs to eliminate the current ATR requirement for separate ECPs. The UFSAR classifies the ECPs as safety related (Category - Non-Plant Protection System). Additionally, the ECPs are qualified as active Seismic Category I components (i.e. the pumps/motors are required to function in an accident/NPH environment).

\section{MAJOR MODIFICATION EVALUATION CRITERIA}

DOE-STD-1189-2008, "Integration of Safety into the Design Process," "was developed to provide consistent DOE complex-wide criteria to be used in determining if a change constitutes a major modification. The standard includes Table 8-1, "Major Modification Evaluation Criteria." The table provides a methodology for evaluating a project against the 10 CFR830, "Nuclear Safety Management," major modification evaluation criteria and was used as a basis for this major modification determination. The table is reproduced herein as Table 1, "Major Modification Evaluation Criteria." The purpose of Table 1 is to focus on the nature of the modification and the associated impact on the existing facility safety basis for the ATR facility.

Major modifications are defined as those changes that "substantially change the existing safety basis for the facility." The guidance for applying the table states that in applying the criteria, the intent is not to automatically trigger the need for a preliminary documented safety analysis (PDSA) if one or more of the criteria are met. Rather, it is intended that each criterion be assessed individually and then an integrated evaluation be performed based on the collective set of individual results. In performing this evaluation, the focus should be on the nature of the modification and its associated impact on the existing facility safety basis. Even a project that results in changes that ripple through the safety basis documents does not "substantially change the existing safety basis for the facility" solely because many parts or pages of the safety basis documentation need to be revised.

A major modification requires the development of a PDSA per 10 CFR 830.206, following the facility modification process as depicted in Figure 1. Since DOE-STD-3009, "Preparation Guide for U. S. Department of Energy Nonreactor Nuclear Facility Documented Safety Analyses,", is not the safe harbor format for the ATR UFSAR, the safety design strategy (SDS) must establish the expectations and the format for integrating the subject major modifications to the update of the UFSAR. 
Table 1. Major modification evaluation criteria.

\section{Major Modification Evaluation Criteria (DOE-STD-1189, Table 8-1)}

\section{Project Information}

The proposed project will replace ATR's original four aged HSB Bingham, horizontal, centrifugal primary coolant pumps and their peripherals including their motors and the butterfly valve (flow control valve to control reactor pressure differential) installed in the PCP discharge piping. The total estimated cost for this project is $\$ 65 \mathrm{~m}$. Like-for-like replacement pumps will, as a minimum, match all operating parameters specified for the currently installed, but now obsolete pumps. The replacement pumps should be of leak-proof design under normal operating conditions. As currently envisioned, the replacement pumps will include VFD technology and eliminate the current ATR requirement for separate ECPs. Under normal operations, the replacement PCPs will be powered, same as the current PCPs, from one of the two commercial electrical buses (E-1 or E-2). Power for each replacement $P C P$ will be through a dedicated VFD. With the VFDs installed and removal of the currently installed butterfly valve (BF-A-14), the VFDs will assume the core differential pressure/flow regulating function currently performed by the butterfly valve.

As noted above, the proposed project includes use of the VFD PCPs to eliminate the current ATR requirement for separate safety-related ECPs. ATR currently has two ECPs, 670-M-10 and -11. ECP 670-M-10 is an ac driven pump powered from the safety-related diesel/commercial bus 670-E15. ECP 670-M-11 is a dc driven pump powered from the safety-related technical safety requirement (TSR) battery bank $670-\mathrm{E}-58$ via the safety-related utility $250 \mathrm{~V}$ DC bus $670-\mathrm{E}-23$. With the VFD option, the ECP function will be provided by the PCP, operating at approximately $1 / 3$ speed as controlled by VFDs. Power to the PCPs for this ECP function will come from the new safety-related E-3 bus with its two quick start emergency diesel generators. As discussed in the introduction, replacement of E-3 and installation of the emergency diesel generators is a separate but interrelated project. It is the subject of a separate major modification determination. 


\begin{tabular}{|c|c|c|c|}
\hline $\begin{array}{c}\text { Evaluation } \\
\text { Criterion } \\
\text { No. }\end{array}$ & $\begin{array}{l}\text { Evaluation } \\
\text { Criteria }\end{array}$ & DOE-STD-1189 Discussion & Replacement of ATR Primary Coolant Pumps and Motors \\
\hline 1 & $\begin{array}{l}\text { Add a new } \\
\text { building or } \\
\text { facility with a } \\
\text { material } \\
\text { inventory } \geq \\
\text { Hazard } \\
\text { Category } 3 \\
\text { (HC 3) limits } \\
\text { or increase } \\
\text { the HC of an } \\
\text { existing } \\
\text { facility? }\end{array}$ & $\begin{array}{l}\text { A new building may be a } \\
\text { structure within an existing } \\
\text { facility segment. That structure } \\
\text { may or may not have direct } \\
\text { process ties to the remainder of } \\
\text { the segment/process. The } \\
\text { requirements of } \\
\text { DOE-STD-1027-92, Change } \\
\text { Notice 1, September 1997, are } \\
\text { used in evaluating Hazard } \\
\text { Categorization impacts. }\end{array}$ & $\begin{array}{l}\text { No. The proposed modification to replace the PCPs does not change the } \\
\mathrm{HC} \text { of the existing facilities or add any new buildings. }\end{array}$ \\
\hline $\begin{array}{c}\text { Evaluation } \\
\text { Criterion } \\
\text { No. }\end{array}$ & $\begin{array}{l}\text { Evaluation } \\
\text { Criteria }\end{array}$ & DOE-STD-1189 Discussion & Replacement of ATR Primary Coolant Pumps and Motors \\
\hline 2 & $\begin{array}{l}\text { Change the } \\
\text { footprint of an } \\
\text { existing } \mathrm{HC} \mathrm{1,} \\
2 \text { or } 3 \text { facility } \\
\text { with the } \\
\text { potential to } \\
\text { adversely } \\
\text { affect any } \\
\text { safety class } \\
\text { (SC) or safety } \\
\text { significant } \\
\text { (SS) safety } \\
\text { function or } \\
\text { associated } \\
\text { structure, } \\
\text { system and } \\
\text { component } \\
\text { (SSC)? }\end{array}$ & $\begin{array}{l}\text { A change in the footprint of an } \\
\text { existing facility requires the } \\
\text { identification and evaluation of } \\
\text { any potential adverse impacts } \\
\text { on SC or SS safety functions or } \\
\text { associated SSC (e.g., structural } \\
\text { qualification, evacuation egress } \\
\text { path, fire suppression spray } \\
\text { pattern) or safety analysis } \\
\text { assumptions. Changes that may } \\
\text { involve adverse impacts require } \\
\text { careful attention to maintaining } \\
\text { adherence to applicable } \\
\text { engineering standards and } \\
\text { nuclear safety design criteria. }\end{array}$ & $\begin{array}{l}\text { No. The ATR footprint will not be changed. The proposed replacement } \\
\text { PCPs will fit within the existing PCP cubicles. The existing flanged } \\
\text { pipe/pump connections may be replaced with welded joints to enhance } \\
\text { reliability and reduce the potential for leakage. With the new PCPs also } \\
\text { performing the ECP function, the current ECP piping arrangements will } \\
\text { need to be modified to remove the ECPs and possibly reroute auxiliary } \\
\text { piping (e.g. chemical cleaning). Power supply to the new PCPs will be } \\
\text { modified to incorporate the VFDs and supply emergency diesel generator } \\
\text { power from the E-3 bus for PCP-(ECP function) operation upon loss of } \\
\text { commercial power. }\end{array}$ \\
\hline
\end{tabular}


INL/EXT-11-22063

Revision 0

\begin{tabular}{|c|c|c|c|}
\hline $\begin{array}{c}\text { Evaluation } \\
\text { Criterion } \\
\text { No. }\end{array}$ & $\begin{array}{c}\text { Evaluation } \\
\text { Criteria }\end{array}$ & DOE-STD-1189 Discussion & Replacement of ATR Primary Coolant Pumps and Motors \\
\hline 3 & $\begin{array}{l}\text { Change an } \\
\text { existing } \\
\text { process or } \\
\text { add a new } \\
\text { process } \\
\text { resulting in the } \\
\text { need for a } \\
\text { safety basis } \\
\text { change } \\
\text { requiring DOE } \\
\text { approval? }\end{array}$ & $\begin{array}{l}\text { A change to an existing process } \\
\text { may negatively affect the } \\
\text { efficacy of an approved set of } \\
\text { hazard controls for a given event } \\
\text { or accident. Likewise, potential } \\
\text { safety concerns associated with } \\
\text { a new process may not be } \\
\text { adequately addressed by the } \\
\text { existing approved control sets. } \\
\text { In this case, it is assumed that } \\
\text { the existing analyses addressed } \\
\text { the hazards associated with the } \\
\text { new or revised process, but the } \\
\text { specified control set(s) may no } \\
\text { longer be valid. The evaluation } \\
\text { of any new hazards introduced } \\
\text { by the revised or new process } \\
\text { should be addressed via } \\
\text { Criterion } 6\end{array}$ & 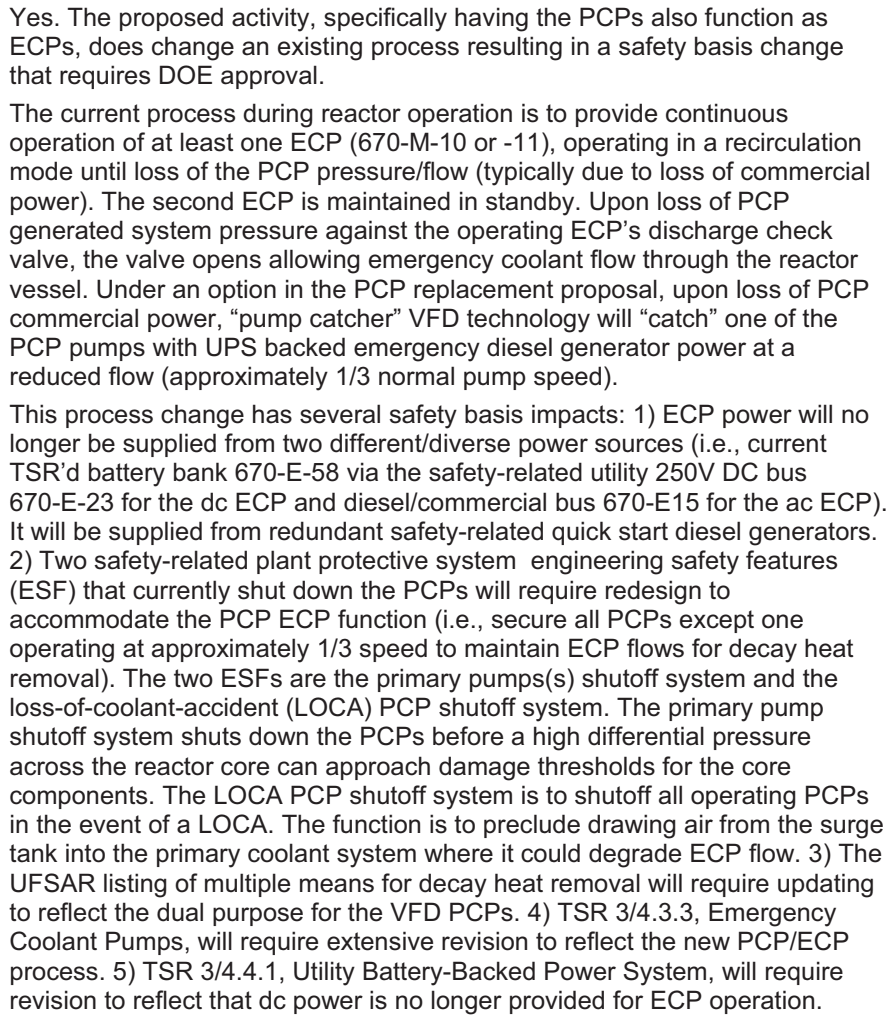 \\
\hline
\end{tabular}




\begin{tabular}{|c|c|c|c|}
\hline $\begin{array}{c}\text { Evaluation } \\
\text { Criterion } \\
\text { No. }\end{array}$ & $\begin{array}{c}\text { Evaluation } \\
\text { Criteria }\end{array}$ & DOE-STD-1189 Discussion & Replacement of ATR Primary Coolant Pumps and Motors \\
\hline 4 & $\begin{array}{l}\text { Utilize new } \\
\text { technology or } \\
\text { government } \\
\text { furnished } \\
\text { equipment } \\
\text { (GFE) not } \\
\text { currently in } \\
\text { use or not } \\
\text { previously } \\
\text { formally } \\
\text { reviewed / } \\
\text { approved by } \\
\text { DOE for the } \\
\text { affected } \\
\text { facility? }\end{array}$ & $\begin{array}{l}\text { This assessment should include } \\
\text { consideration of the impact that } \\
\text { the use of new technology } \\
\text { (including technology scale-up } \\
\text { issues) or GFE may have on the } \\
\text { ability to specify the applicable } \\
\text { nuclear safety design criteria } \\
\text { with a high degree of certainty in } \\
\text { the early stages of the project. } \\
\text { Additionally, refer to GFE } \\
\text { discussion in Section } 8.3 \text {. GFE } \\
\text { may have a technical baseline } \\
\text { that is not directly and fully } \\
\text { supportive of the project } \\
\text { functional and performance } \\
\text { requirements. An example } \\
\text { would be employing a new } \\
\text { technology for removal of certain } \\
\text { nuclides from a waste stream. }\end{array}$ & $\begin{array}{l}\text { Yes. The use of VFD and VFD "pump catcher" technology for the PCPs is } \\
\text { not currently in use and has not been previously formally } \\
\text { reviewed/approved by DOE for ATR. However, VFD technology has } \\
\text { several decades of commercial use and experience. The ATR } \\
\text { probabilistic risk assessment will have to be updated, reflecting the } \\
\text { changes for supplying ECP flows including VFD reliability, to confirm that } \\
\text { the proposed activity maintains or reduces the core damage frequency } \\
\text { (CDF) for the ATR. }\end{array}$ \\
\hline
\end{tabular}




\begin{tabular}{|c|c|c|c|}
\hline $\begin{array}{c}\text { Evaluation } \\
\text { Criterion } \\
\text { No. }\end{array}$ & $\begin{array}{c}\text { Evaluation } \\
\text { Criteria }\end{array}$ & DOE-STD-1189 Discussion & Replacement of ATR Primary Coolant Pumps and Motors \\
\hline 5 & $\begin{array}{l}\text { Create the } \\
\text { need for new } \\
\text { or revised } \\
\text { safety SSCs? }\end{array}$ & $\begin{array}{l}\text { Consideration should be given } \\
\text { to the relative complexity of the } \\
\text { controls and the ease with which } \\
\text { the controls can be } \\
\text { implemented. The use of a } \\
\text { complicated multi-channel } \\
\text { Safety Class seismically } \\
\text { qualified instrumented system to } \\
\text { provide multiple interlock and } \\
\text { alarm functions would typically } \\
\text { pose a higher risk to the project } \\
\text { than the use of a safety } \\
\text { significant passive design } \\
\text { feature. The degree of design } \\
\text { and regulatory uncertainty } \\
\text { should be addressed for this } \\
\text { criterion for the development, } \\
\text { review, and approval of new or } \\
\text { revised safety analysis and } \\
\text { attendant controls (e.g., } \\
\text { presence of multiple } \\
\text { regulatory/technical agencies on } \\
\text { a single project). }\end{array}$ & $\begin{array}{l}\text { Yes. It is expected that the proposed activity will result in a revised list of } \\
\text { safety-related SSCs. Specifically, as currently proposed, the existing } \\
\text { ECPs will be deleted from the list. The PCPs and their associated } \\
\text { components, picking up the ECP function, will be classified as } \\
\text { safety-related active Seismic Category I. }\end{array}$ \\
\hline
\end{tabular}




\begin{tabular}{|c|c|c|c|}
\hline $\begin{array}{c}\text { Evaluation } \\
\text { Criterion } \\
\text { No. }\end{array}$ & $\begin{array}{c}\text { Evaluation } \\
\text { Criteria }\end{array}$ & DOE-STD-1189 Discussion & Replacement of ATR Primary Coolant Pumps and Motors \\
\hline 6 & $\begin{array}{l}\text { Involve a } \\
\text { hazard not } \\
\text { previously } \\
\text { evaluated in } \\
\text { the } \\
\text { Documented } \\
\text { Safety } \\
\text { Analysis? }\end{array}$ & $\begin{array}{l}\text { Hazards can include the } \\
\text { introduction of an accident or } \\
\text { failure mode of a different type } \\
\text { from that previously analyzed in } \\
\text { addition to radiological or } \\
\text { toxicological hazards. The need } \\
\text { to address a new hazard early in } \\
\text { the design process may lead to } \\
\text { some degree of uncertainty } \\
\text { related to the proper } \\
\text { specification of applicable } \\
\text { nuclear safety design criteria. In } \\
\text { such cases, this uncertainty } \\
\text { should be addressed within this } \\
\text { evaluation. }\end{array}$ & $\begin{array}{l}\text { No. As discussed in Section } 3 \text { of this document, replacement of the PCPs } \\
\text { does not involve any hazards not previously evaluated in the ATR } \\
\text { UFSAR. However, additional evaluation is required to ascertain if the } \\
\text { VFDs introduce a failure mode of a different type from that previously } \\
\text { analyzed in the UFSAR. One question is whether the VFD is capable of } \\
\text { failing in an overspeed mode potentially resulting in high pressures or } \\
\text { flows. This applies to the VFD failure modes for the PCP function as well } \\
\text { as the ECP function. }\end{array}$ \\
\hline \multicolumn{4}{|c|}{$\begin{array}{l}\text { Summary and Recommendation: Three of the six criteria (Criterion } 3,4 \text {, and } 5 \text { ) were tripped in this major modification evaluation. As discussed } \\
\text { above, the project does not introduce any new significant hazards. However, the strategy for equipping the replacement PCPs with VFDs and } \\
\text { having the PCPs also function as ECPs will require significant safety basis changes requiring DOE approval (see Criterion No. } 3 \text { discussion } \\
\text { above). The strategy to use the PCPs in a dual ECP/PCP role requires careful attention to maintaining adherence to applicable and credited } \\
\text { engineering and nuclear safety design criteria (e.g., active seismic qualification, redundancy and diversity for safety functions) to ensure no } \\
\text { adverse impacts to their designated safety functions. Based on these considerations, it is concluded that this project constitutes a major } \\
\text { modification and will, therefore, require the development, review, and approval of a PDSA. It is recommended that the project proceed } \\
\text { accordingly. Also, since DOE-STD-3009 is not the safe harbor format for the ATR UFSAR, the SDS must establish the expectations and the } \\
\text { format for the PSDR (if needed) and PDSA to integrate the subject major modifications into the ATR UFSAR. }\end{array}$} \\
\hline
\end{tabular}


INL/EXT-11-22063

Revision 0

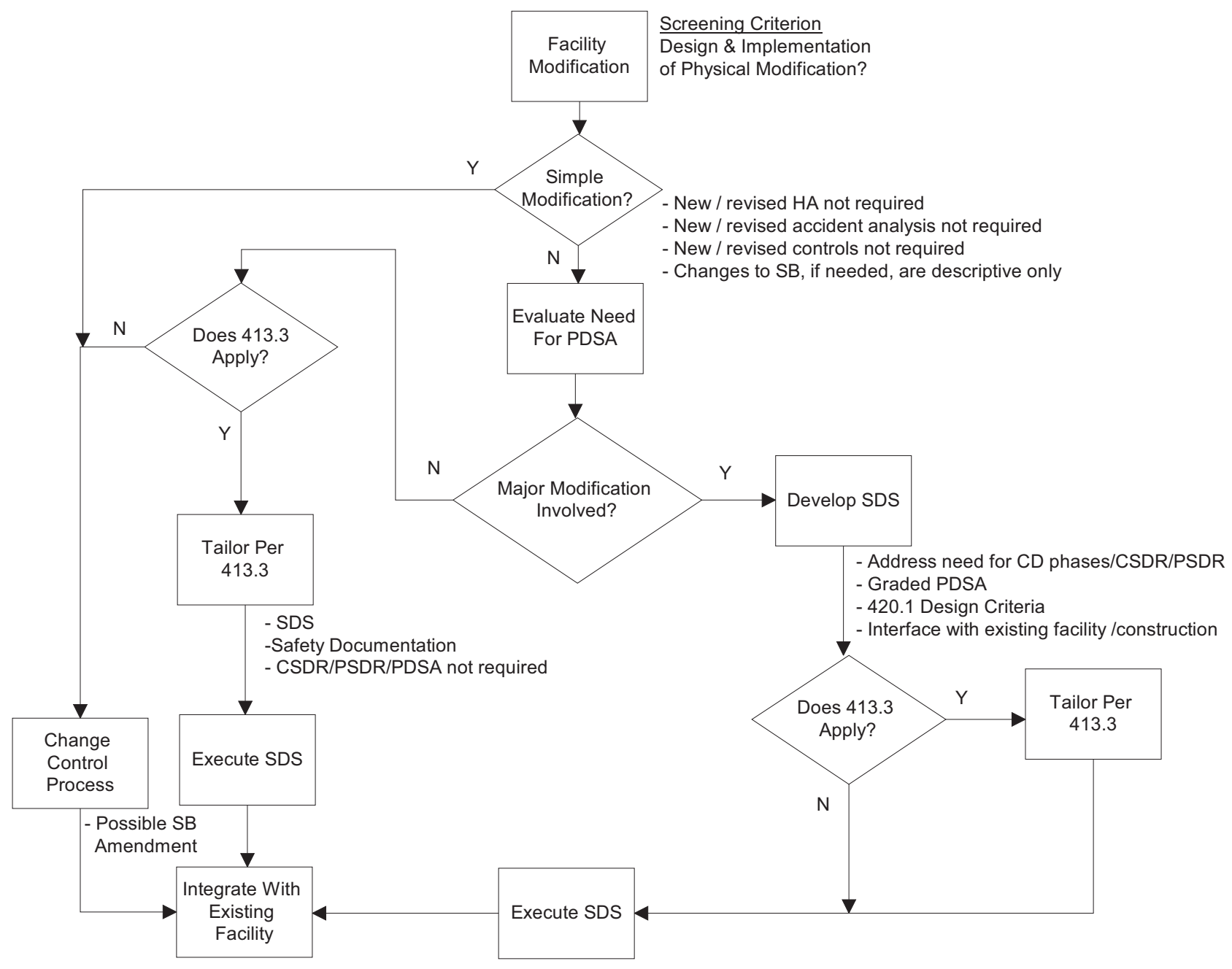

Figure 1. Facility modification process (taken from DOE-STD-1189, Figure 8-1). 
INL/EXT-11-22063

Revision 0

\section{CONCLUSION}

The major modification criteria evaluation of the project pre-conceptual design identified several issues that lead to the conclusion that the project is a major modification:

1. Evaluation Criteria \#3 (Change of existing process). The proposed strategy for equipping the replacement PCPs with VFDs and having the PCPs also function as ECPs will require significant safety basis changes requiring DOE approval.

2. Evaluation Criteria \#4 (Use of new technology). The use of VFD and VFD "pump catcher" technology for the PCPs is not currently in use and has not been previously formally reviewed/approved by DOE for ATR. It is noted that VFD technology has several decades of commercial use and experience. However, the ATR probabilistic risk assessment will have to be updated, reflecting the changes for supplying ECP flows including VFD reliability, to confirm that the proposed activity maintains or reduces the CDF for the ATR.

3. Evaluation Criteria \#5 (Create the need for new or revised safety SSCs). It is expected that the proposed activity will result in a revised list of safety-related SSCs. Specifically, as currently proposed, the existing ECPs will be deleted from the list. The PCPs and their associated components, picking up the ECP function, will be classified as safety-related active Seismic Category I.

The positive major modification determination is driven by the proposed strategy for equipping the replacement PCPs with VFDs and having the PCPs also function as ECPs. These changes will require significant safety basis changes requiring DOE approval. The strategy to use the PCPs in a dual ECP/PCP role requires careful attention to maintaining adherence to applicable and credited engineering and nuclear safety design criteria (e.g., active seismic qualification, redundancy and diversity for safety functions) to ensure no adverse impacts to their designated safety functions. The safety analysis supporting this major modification will need to be tailored appropriately as discussed in the following text from DOE-STD-1189, Chapter 8:

"Where a major modification is found to exist, an SDS must be developed that addresses (1) the need for a CSDR or PSDR (as well as the required PDSA) to support project phases, (2) the graded content of the PDSA necessary to support the design and modification, (3) the application of nuclear safety design criteria, and (4) the interface with the existing facility, its operations, and construction activities."

\section{REFERENCES}

1. Mission Need Statement for Advanced Test Reactor Reliability Sustainment Project, March 2011 Draft.

2. Curtiss Wright Flow Control Company, "Alternative Concepts Study for the Idaho National Laboratory Advanced Test Reactor Primary Coolant Pump Replacement (G932),” NNE-024-10, August 26, 2010.

3. Curtiss Wright Flow Control Company, "Final Scoping Study Report for the Idaho National Laboratory Advanced Test Reactor Primary Coolant Pump Replacement (G932)," NNE-025-10, September 28, 2010.

4. SAR-153, "Upgraded Final Safety Analysis Report for the Advanced Test Reactor,” Rev. 30, February 2011. 
5. DOE-STD-1189-2008, "Integration of Safety into the Design Process," Department of Energy, March 2008

6. 10 CFR 830, Subpart B, "Nuclear Safety Management," Code of Federal Regulations, Office of the Federal Register, current revision.

7. DOE-STD-3009-94, Change 3, "Preparation Guide for U. S. Department of Energy Nonreactor Nuclear Facility Documented Safety Analyses,” Department of Energy, March 2006. 